RICHARD BUTTERWICK

UNIVERSITY COLLEGE LONDON

\title{
Postawa polityczna prymasa Michała Jerzego Poniatowskiego w latach 1789-1792*
}

Tematyka niniejszego artykułu styka się z kilkoma wątkami w badaniach i twórczości Zofii Libiszowskiej. Poświęcała Ona wiele uwagi Polakom przebywającym w Anglii w drugiej połowie wieku XVIII, czynionym przez współczesnych porównaniom między Polską Rewolucja a Rewolucją Francuska oraz modelowi ustroju brytyjskiego w polskiej publicystyce stanisławowskiej ${ }^{1}$. Tu przedstawiam stosunek do Rewolucji Polskiej i Francuskiej jednego $z$ owych polskich podróżników nad Tamizę. Prymas Michał Jerzy Poniatowski (1736-1794) spędził siedem miesięcy w Anglii między listopadem 1790 a czerwcem 1791 r. w toku prawie dwuletniego Grand Tour po Italii, Francji i Anglii. Jego itinerarium i zakupy na deszczowej wyspie opisała szczegółowo Angela Sołtys ${ }^{2}$. W tym studium chodzi mi przede wszystkim o wnioski, jakie prymas wyciagnął

* Większość artykułu pokrywa się z różnymi częściami mojej monografii Polska Rewolucja a Kościół katolicki 1788-1792, przekł. M. Ugniewski [w druku]. Tam znajduja się również polskie tłumaczenia podanych tu cytatów obcojęzycznych. Nie zmodernizowałem ani nie poprawiłem cytatów w żadnym języku.

1 Por. m.in. Misja polska $w$ Londynie $w$ latach 1769-1795, Łódź 1966; Model angielski $w$ publicystyce polskiego Oświecenia, „Sprawozdania z Czynności i Posiedzeń Naukowych Łódzkiego Towarzystwa Naukowego" 1969, R. XXIII, nr 10, s. 1-10; Edmund Burke a Polska, „Kwartalnik Historyczny” 1970, R. LXXVII, nr 1, s. 63-76; Życie polskie $w$ Londynie $w$ XVIII wieku, Warszawa 1972; Polska reforma w opinii angielskiej, [w:] Sejm Czteroletni i jego tradycje, red. J. Kowecki, Warszawa 1991, s. 63-74; Odgłosy Konstytucji 3 Maja na Zachodzie, [w:] Konstytucja 3 Maja $w$ tradycji i kulturze polskiej, red. A. Barszczewska-Krupa, t. I, Łódź 1991, s. $70-81$.

2 A. S o 1 ty s, Opat z San Michele. Grand Tour prymasa Poniatowskiego i jego kolekcje, Warszawa 2008. 
z obserwacji Francji i Anglii, w kontekście jego zaangażowania w politykę Sejmu Czteroletniego w okresie od jesieni 1791 do wiosny 1792 r. Skupiam się nad jego stanowiskiem wobec Konstytucji 3 maja, licytacji królewszczyzn i cenzury duchownej oraz nad jego stosunkami $z$ posłem francuskim. Natomiast nie zajmuję się tutaj kwestiami wprawdzie ważnymi w tym okresie dla stosunków między Rzeczapospolita a Stolica Apostolska, w odniesieniu do których Poniatowski nie prezentował jasnego stanowiska - tak zwanym kodeksem Stanisława Augusta i autokefaliczna hierarchia prawosławną ${ }^{3}$. Zaczynam swoje rozważania od okoliczności, w których prymas opuścił we wrześniu 1789 r. Polskę.

Latem roku 1789 Michał Jerzy Poniatowski był politykiem przegranym i człowiekiem załamanym. Legł w gruzach system polityczny, który wraz ze swoim bratem Stanisławem Augustem budował wytrwale od kilkunastu lat, który jeszcze rok wcześniej zdawał się mieć całkiem dobre perspektywy. Sejm warszawski roku 1788 wyrwał Rzeczpospolita $z$ ponurej, lecz w miarę bezpiecznej podległości Rosji i - zdaniem prymasa - rzucił ją w przepaść. Taki skok mógł się kończyć, jak prymas nieraz ostrzegał swoich ziomków, tylko katastrofa. W związu $z$ tymi przestrogami spotkał go los Kasandry. Obrzucono go obelgami i pomówieniami, szczególnie przez sejmowych „szczekaczy”, na czele z posłem inflanckim Stanisławem Kublickim ${ }^{4}$. Ponadto obróciły się w niwecz nadzieje Poniatowskiego na zatrzymanie rządów w biskupstwie krakowskim (obok arcybiskupstwa gnieźnieńskiego). Po wielomiesięcznych pertraktacjach w sprawie obsad biskupstw, określonych przez nuncjusza apostolskiego Ferdinanda Marię Saluzzo jako „intrighi, e simonie”, 17 lipca 1789 r. hetmańska opozycja skorzystała $z$ antyklerykalnych nastrojów szlacheckiej prowincji, ujawnionych już podczas

3 Por. M. L o r e t, Watykan a Polska $w$ dobie rozbiorów 1772-1795, „Przegląd Współczesny” 1934, t. XLIX, s. 337-360; W. S z a frań s ki, Kodeks Stanisława Augusta, Poznań 2007; E. S a kow ic z, Kościót prawosławny w Polsce w epoce Sejmu Wielkiego 1788-1792, Warszawa 1935; K. Paździor, Polityka Sejmu Czteroletniego wobec kościołów wschodnich [praca doktorska], Uniwersytet Śląski, Katowice 2000; R. Butte rwick, Deconfessionalization? The Policy of the Polish Revolution towards Ruthenia, 1788-1792, "Central Europe” 2008, vol. VI, nr 2, s. 91-121.

4 Por. W. Ka linka, Sejm Czteroletni [1880-1887], wyd. IV, t. I, Warszawa 1991; Z. Z i e li ń s k a, Poniatowski, Michał Jerzy, [w:] Polski słownik biograficzny [dalej: PSB], t. XXVII, Wrocław 1983, s. 455-471, a zwłaszcza 462-464; Zagadki Sejmu Czteroletniego, oprac. E. Rabowicz i B. Krakowski, wyd. J. Kowecki, Warszawa 1996, s. 158-159. 
sejmików poselskich roku 1788 i debat podatkowych wiosną roku 1789, aby przeznaczyć majątki biskupstwa krakowskiego na wojsko. W miarę wakowania biskupstw, biskupi obu obrządków mieli stać się płatnymi urzędnikami państwa. To prawo, pod znamiennym tytułem Fundusz dla woyska, zagroziło schizmą między Rzeczapospolita a Stolica Apostolską ${ }^{5}$.

Sprawa biskupstwa krakowskiego głęboko zraniła Poniatowskiego. Austriacki chargé d'affaires, Benedikt de Caché, donosił swemu dworowi już 25 lipca 1789 r., że „Herr Fürst Primas lieget schon seit einiger Zeit auf seinem Landgut Jablonna, aus vielen Verdruß über den so verwirrten und gar keine Entwicklungs= Aussicht zeigenden gang den Pohlnischen Angelegenheiten, krank"6. Natomiast depesza francuskiego agenta, Josepha Auberta, z 3 sierpnia daje unikatowy wręcz wgląd w stan jego umysłu i duszy: „Le Primat s'est retiré depuis plus de trois semaines à sa campagne distante de quelques lieues de cette capitale sous le pretexte d'une indisposition qui a été três legere, et qui n'existe plus depuis longtemps. La vraie raison de son éloignement est le dégout que lui cause la maniere dont les affaires sont menées à la Diette depuis quelques tems. Ce Prince m'a fait l'honneur de m'inviter à aller le voir et j'ai passé une journée chez lui en três petite

5 Por. J. M i ch a ls ki, Sejmiki poselskie 1788 roku, [w:] i d e m, Studia historyczne $z$ XVIII $i$ XIX wieku, red. W. Kriegseisen i Z. Zielińska, t. I (Polityka i społeczeństwo), Warszawa 2007, s. 217-284, a zwłaszcza 276-277; R. B u t t e r w i c k, „Intrighi e simonie” wokół biskupstwa krakowskiego w 1789 roku, „Kwartalnik Historyczny" 2004, t. CXI, nr 3, s. 103-126; i d e m, O ratunek ojczyzny. Sprawa opodatkowania duchowienstwa katolickiego w poczatkach Sejmu Czteroletniego, [w:] Spory o państwo $w$ dobie nowożytnej. Między racja stanu a partykularyzmem, red. Z. Anusik, Łódź 2007, s. 229-241; i d e m, „Lepiej iest mieć pewne $100 \mathrm{~m}$. $w$ republikanckim rzadzie, niźli krocie za kordonem". Sprawa biskupstwa krakowskiego na sesji sejmowej 17 lipca 1789 roku - przykład perswazji oratorskiej, [w:] Literatura, historia, dziedzictwo. Prace ofiarowane Profesor Teresie Kostkiewiczowej, red. T. Chachulski i A. Grześkowiak-Krwawicz, Warszawa 2007, s. 448-457; i d e m, Jak nie doszło do schizmy. Rzeczpospolita a Stolica Apostolska $w$ czasie Sejmu Czteroletniego, „Kwartalnik Historyczny” 2009, t. CXVI, nr 3, s. 73-90.

6 Benedikt de Caché do Wenzla Antona v. Kaunitza, 25 VII 1789, Haus- Hofund Staatsarchiv, Wiedeń [dalej: HHStA], Polen II 51, depesza 562, k. 64. Por. W. Ka lin k a, op. cit., t. I, s. 417. Tymczasem ks. Krzysztof Żórawski informował prymasa o bieżacych sprawach kościelnych zarówno listownie, jak i przyjeżdżając osobiście do Jabłonny. Listy, niektóre $z$ adnotacjami prymasa, znajduja się w Archiwum XX. Misjonarzy na Stradomiu w Krakowie [dalej: AMS Poniatowski], A I 24. Zawdzięczam swoją znajomość tych zbiorów po prymasie i Żórawskim uprzejmości dr Angeli Sołtys i ks. Wacława Umińskiego CM. 
société. Dans les fréquentes occasions que j'ai eues de l'entretenir, il m'a confirmé tout ce que je connoissois déja de son mecontentement. "Tant, m'a t'il dit, que deux ou trois personnes et surtout ce fripon de P[rin]ce Sapieha, ce sont ses mots, qui sont en possession d'ameuter toute la chambre, se croiront permir de mener à tout, de ne respecter aucune proprieté, de se livrer à des projets gigantesques, et qu'ils présumeront follement assés de leur propre forces pour pouvoir les conduire à leur execution sans concours, sans appui des Puissances interessées à notre Conservation; que puis-je favie et comment arrêter cette démence qui s'est emparée de toutes les têtes? On a fait tout ce qu'on a pû pour anéantir mon crédit; on y est parvenu à force des insinuations, et on me prétant des vües que je n'eus jamais; que voulez vous - en conséquence que je fasse avec ces forcenés. Je vous avoüe, m'atil ajouté, mais très en secret, que si cela continue, je prendrai le parti d'aller aux Eaux pour y attendre plus tranquillem[en]t encore ce qui pourra en resulter; mais ecrivez tout cela et que Sa M[ajes]te Très Chrét[ienn]e nous donne quelque bon conseil, ceux de tout ce qui nous entoure sont interessés à tout embrouiller et il est de la dignité et peut être de l'intéret du Roi de ne pas nous abandonner au hazard des événemens qui nous ménacent""7.

Tragikomiczny pomysł, aby $\mathrm{w}$ tym momencie poprosić Ludwika XVI o radę, ukazuje desperację Poniatowskiego. Powtórzył tę myśl, kiedy Aubert odwiedził go ponownie, 29 sierpnia ${ }^{8}$. Prymas zapowiedział już wcześniej zamiar odwiedzenia doktora Balthazara Tralles'a we Wrocławiu, w liście datowanym 2 sierpnia. Tłumaczył marszałkowi sejmowemu Stanisławowi Małachowskiemu, że „po paroxyźmie nudney febry osłabione oczy i nogi, oraz sen mizerny wcale niezdolnym teraz mię czynia do pracy i ceremoniałów mieyskich”. Na początku września napisał do ks. Gaetano Ghigiottiego, sekretarza króla do spraw włoskich i kościelnych, że nieszczęsna sprawa biskupstw („cette affaire malheureuse”) pogorszyła stan jego zdrowia9. Mówiono w Warszawie, że prymas był „prawdziwie słaby,

7 Josph Aubert do Armanda de Montmorina, 3 VIII 1789, Archives du Ministère des Affaires Étrangères w Paryżu, Correspondance Politique [dalej: AMAE, CP], Pologne 316, k. 394-396, depesza 30.

8 J. Aubert do A. de Montmorina, 2 IX 1789, AMAE, CP Pologne 316, k. 440441, depesza 33.

${ }_{9}$ M.J. Poniatowski [dalej: MJP] do Stanisława Małachowskiego, Jabłonna, 2 VIII 1789, AMS Poniatowski A I 27, s. 641; MJP do Kajetana Ghigiottiego, 6 IX 1789, AGAD, Archiwum ks. Kajetana Ghigottiego [dalej: AGhig.] nr 515a, t. II, k. 83. 
sypiać niemoże, iakies fhantasmata mu się roią". Jego trzymiesięczna nieobecność w stolicy przed wyjazdem rodziła nawet spekulacje, że oszalał10.

Prawie dwa lata później Stanisław August przedstawiał wyjazd prymasa jako „absolument nécessaire”, ponieważ „sa presence ici auroit éloigné et peut-être empêché” szczęśliwą rewolucję 3 maja 1791 r. ${ }^{11}$ Brzmi to tak, jakby król prosił swojego brata, by ten wyjechał lub przynajmniej uczestniczył w tej decyzji. Jest to zreszta ogólnie przyjęta interpretacja12. Jednakże jeden ze współczesnych świadków donosił, że król usiłował przekonać prymasa do pozostania w Polsce ${ }^{13}$. Możemy jedynie spekulować, czy prymas wierzył, czy nie, że król został dotknięty ogólna „demencją” (jak to określił $\mathrm{w}$ rozmowie $\mathrm{z}$ Aubertem). Ale wydaje się bardziej prawdopodobne, że prymas, na równi $z$ królem, nie widział większego sensu w tego rodzaju kontrataku, jaki proponował wielokrotnie ambasador rosyjski, Otto Magnus von Stackelberg14. Trzy i pół roku później prymas oświadczył biskupowi wileńskiemu Ignacemu Massalskie-

10 Wincenty Gurski do Leonarda Marcina Świejkowskiego, 2 IX 1789, Biblioteka Zakładu Narodowego im. Ossolińskich we Wrocławiu [dalej: BOss.], rkps 6353, s. 533. O tych pogłoskach napisał MJP do bratanicy Marii Teresy Tyszkiewiczowej [dalej: MTT], Londyn 13 I 1791 i także w niedatowanym liście do niej z końca kwietnia 1791 r., AGAD, Archiwum księcia Józefa Poniatowskiego i Marii Teresy Tyszkiewiczowej [dalej: AJP] nr 1066, s. 52, 111. Na te listy również uprzejmie zwróciła mi uwage dr Angela Sołtys.

11 Stanisław August [dalej: SA] do Maurice'a Glayre'a, 25 VI 1791, [w:] S t a $\mathrm{n}$ is ław A u g u st, M a u rice G lay re, Correspondance relative aux partages de la Pologne, wyd. E. Mottaz, Paris 1897, s. 266. Emanuel Rostworowski poprawił datę (podana jako 21 VI 1791) po zapoznaniu się $z$ oryginałem.

12 Z. Z i e liń s k a, op. cit., s. 464; J. M i c h a 1 s k i, Stanisław August Poniatowski, Warszawa 2009, s. 54.

13 W. Gurski do L.M. Świejkowskiego, 2 IX 1789, BOss., rkps 6353, s. 533.

14 Ks. Hugo Kołłąaj napisał w połowie 1790 r. (dla Fryderyka Wilhelma II, choć niewiadomo, czy król pruski faktycznie otrzymał francuski przekład tego listu), że generał Jan Komarzewski dobrowolnie wyjechał zagranicę, aby ukrócić „despotycznym Ambassadora rozkazom”, prymas wyjechał „aby partya Moskiewska nie miała na czele swoim tak mocnego Szeffa", a długoletnia metresa królewska Elżbieta Grabowska „do wód odiechała ażeby iey Dom nie był Domem obcowania Króla z przyiaciołmi moskiewskimi". Tymczasem kasztelan czerski, Tomasz Ostrowski, „stopniami oświecał króla”. Biblioteka Polskiej Akademii Umiejętności i Polskiej Akademii Nauk w Krakowie [dalej: BPAU], rkps 186, s. 162. Sugestia, że czołowi zwolennicy "trzymania się $z$ Rosja” wyjechali $z$ własnej inicjatywy, aby łatwiej było „wyprowadzić słabego króla $z$ bojaźni” jest wysoce tendencyjna, jednak w pewnym stopniu to pismo wzmacnia interpretację, że Stanisław August nie naciskał na swego brata, aby ten wyjechał. 
mu, że on musiał wyjechać, podczas gdy król musiał zostać i ustąpić $^{15}$. W tym czasie Stanisław August poinformował posła polskiego w Petersburgu Augustyna Debolego, że prymas, „zgrzyiony wszystkiemi dokuczliwościami, ktore zadał Seym teraznieyszy, tak hoynie mnie y Jemu osobiście y Duchowieństwu w powszechności, ucierpiał znacznie na zdrowiu, tak dalece, że się po długim czekaniu w Jabłonnie determinował się poiechać do Wrocławia do Tralesa. Ten Doktor wielce się wsławiał, a mianowicie między Polakami”. Ujawnił swoje zaniepokojenie, że wyjazd prymasa „narobi znowu wiele gadania; a może y złosliwych zamysłow; bo między lekkiemi głowami, ktorych okazuie się dosyć teraz w Polszcze, formalnie nieci się emulacya, żeby coś podobnego zrobić temu co się działo we Francyi, od 14 do 16 Lipca. Bogdayby lepiey emulowali z Francuzami o to, co oni na swoim Seymie 4 Aug. zrobili"16. Zawsze swiadom paraleli między soba a Ludwikiem XVI, być może wyobrażał sobie swojego brata w roli hrabiego Artois (przyszłego Karola X), który wtedy wyjechał $z$ Francji.

Michał Poniatowski opuścił Jabłonnę 31 sierpnia 1789 r. ${ }^{17}$ Po drodze zatrzymał się w swojej rezydencji w Łowiczu. 9 września w Gnieźnie odbył spóźniony i zorganizowany naprędce ingres i wizytację swej katedry, w asyście szlachty $z$ miejscowej komisji podatkowej. W krótkim przemówieniu mówił o staropolskim szacunku dla duchowieństwa i pobożności. Wydał ucztę i „wina dobrego" dla 50 prowincjonalnych notabli, przenocował i wyjechał. Nigdy więcej nie modlił się już u grobu św. Wojciecha. Po przybyciu do Wrocławia ogłosił zamiar udania się do Włoch i dokonał formalności dotyczacych zarządu archidiecezji pod swa nieobecność18. Pozostawił archidiecezję gnieźnieńską i diecezję krakowska

15 MJP do Ignacego Massalskiego, Warszawa 16 I 1793, [w:] Ł. Ką d zi ela, Prymas Michat Poniatowski wobec Targowicy, "Przeglad Historyczny” 1994, t. LXXXV, s. 433-442, a zwłaszcza 437.

16 SA do Augustyna Debolego, 26 VIII 1789, AGAD, Zbiór Popielów [dalej: ZP] $\mathrm{nr} 414, \mathrm{k}$. 431-432. Chodziło królowi o poświęcenie przywilejów szlacheckich i duchownych w Zgromadzeniu Narodowym w nocy z 4 na 5 VIII 1789.

17 Ks. Józef Konstanty Bogusławski do ks. Michała Poczobuta, bez daty [Warszawa, po 16 IX 1789], Vilniaus Universiteto Biblioteka w Wilnie, Fondas 2 DC 38, nr 31.

18 A. S ołty s, op. cit., s. 60. Oprócz cytowanej tu wersji z Archiwum Archidiecezjalnego w Gnieźnie [dalej: AAG], Acta Postcuralia, znany jest jeszcze inny oficjalny opis ingresu i wizytacji, który wyjawia wysoka liczbę kanoników nieobecnych. Por. Acta Capituli Gnesnensis, Archivum Capituli [dalej: AAG, ACap.], B39, k. 186-195. Mowa... prymasa przy pierwszym jego wstepie do archikatedry 
w kompetentnych rękach - ks. dziekana warszawskiego Krzysztofa Żórawskiego i ks. biskupa sufragana krakowskiego Józefa Olechowskiego. Ten pierwszy informował prymasa na bieżąco o sprawach kościelnych w Rzeczypospolitej, prowadził również korespondencję z posłem Rzeczypospolitej w Rzymie, kardynałem Tommaso Anticim. W dalszym ciagu Poniatowski miał głos w „ważniejszych prezentach"19. Pomimo różnic poglądów politycznych, poprosił najuprzejmiej marszałka nadwornego litewskiego Ignacego Potockiego o opiekę, podczas swej nieobecności, nad Komisją Edukacji Narodowej20.

Wyjazd prymasa usuną jedna $\mathrm{z}$ przeszkód $\mathrm{w}$ zbliżeniu króla z Puławianami. Ale „szermierka” Stanisława Augusta z Ignacym Potockim potrwała jeszcze ponad rok, zanim mogło dokonać się owo przegrupowanie ${ }^{21}$. Konieczność uniknięcia schizmy między Rzecząpospolita a Stolica Apostolską tworzyła jedyna płaszczyznę, na której mogliby oni współpracować ${ }^{22}$.

Poniatowski spędził ponad rok we Włoszech. Ciepłe powietrze neapolitańskie pomogło mu $\mathrm{w}$ powrocie do zdrowia, które ucierpiało jeszcze bardziej na skutek chronicznej niestrawności i ostrych konwulsji towarzyszących podróży na południe. Jego główne zajęcia polegały na odwiedzaniu miejscowości interesujących pod względem naukowym i topograficznym, nawiazywaniu kontaktów $z$ artystami oraz kupowaniu dzieł sztuki dla siebie i brata. Oczywiście, niektóre obrazy i rzeźby miały charakter sakralny, ale jego główna motywacją było kolekcjonerstwo ${ }^{23}$.

gnieźnieńskiey dnia 9 września roku 1789 miana, Warszawa, b.d. [1789]. Por. J. Kit ow i c z, Pamiętniki czyli historia polska, oprac. P. Matuszewska i Z. Lewinówna, Warszawa 1971, s. 421-422 (cytat). Prymas potwierdził swój zamiar wyjazdu do Italii na kilka miesięcy w liście do S. Małachowskiego $z$ Wrocławia, 14 IX 1789, AMS Poniatowski, A I 27, s. 644-645.

19 Świadcza o tym liczne listy zachowane w: AMS Poniatowski, A I 24 i 25. Por. S. B i s k u p s k i, Krzysztof Żórawski, polski kanonista XVIII stulecia, Włocławek 1950; M. P ę c k o w s ki, Józef Olechowski, archidiakon i suffragan krakowski 1735-1806 (szkic historyczny), Kraków 1926.

20 MJP do Ignacego Potockiego, Wrocław 16 IX 1789, AMS Poniatowski, A I 27, s. 646-648.

21 Por. E. R o s tw o r ow s k i, „Marzenie dobrego obywatela”, czyli królewski projekt konstytucji, [w:] id e m, Legendy i fakty XVIII wieku, Warszawa 1963, s. 265-464, a zwłaszcza 288-354.

22 Por. R. B u t t e r w i c k, Jak nie doszło do schizmy..., passim.

23 Por. A. S ołty s, op. cit., s. 55-197. 
Chociaż był dobrze poinformowany o tym, co działo się w kraju, m.in. przez Stanisława Augusta za pośrednictwem ks. Ghigottiego, powstrzymywał się od udzielania rad swemu bratu. Uważał, że tylko cud mógł już uratować Ojczyznę od katastrofy, choć żywił pewne nadzieje odnośnie do postawy króla węgierskiego i czeskiego (później cesarza) Leopolda II. Wiosna roku 1790 napisał do siostrzenicy, Urszuli Mniszchowej: „Je Continue a faire Les Souhaits les plus sinceres pour le Bien être de ma Patrie du Roi et de Vous tous. J'addresse des voeux ardents au Ciel, qu'Il nous eclaire et nous fasse eviter Les ecueils sur cette mere orageuse dans laquelle nous sommes Souvent battues Sens boussole et Pilote pourvu d'autorité et de droits Suffisants. Il faut Sens doute miracles pour nous faire arriver a bon port. La mort d'empereur operera peutêtre Ce miracle. Bien des gens assurent que Les intentions de Son Successeur sont tres pacifiques, un homme d'esprit vient neanmoins de me dire qu'il a plus d'ambition que Son Frere, que conclure de tout ce verbiage assé inutile de ma part, rien d'autre Sinon que n'ajant pas assé de Santé ni de Tête, pour continuer donner des Conseils efficaces a Varsovie. Je serais foux d'en hazarder a cette distançe de lieux et de temps dans un moment a l'autre Je Sens tout Le prix de l'amitié et du Scavoir du personage m'a voulu inserer quelque lignes dans Votre lettre"24.

Poniatowski przybył do Rzymu 13 lutego 1790 r., a dziesięć dni później został przyjęty przez papieża, jako „abbé de Saint-Michel”. Pius VI wolałby przyjmować go jako prymasa, ale Poniatowski miał „ses raisons" - pisał zagadkowo Antici. Być może miało to zapewnić mu możliwość bardziej swobodnego wypowiadania się, bez ograniczeń dyplomatycznej etykiety. Być może nie chciał wywołać komplikacji w Warszawie, gdzie sprawy dyplomatyczne należały do kompetencji sejmowej deputacji do interesów zagranicznych ${ }^{25}$. Obecność Poniatowskiego w Rzymie stanowiła okazję do wzajemnego zapoznania się prymasa $z$ kurią rzymska. Polityczne akcje prymasa stały nisko, więc hiperbolicznie brzmią przestrogi nuncjusza, że Poniatowski, przez swoich adherentów w sejmie, dąży do stwo-

24 MJP do Urszuli Mniszchowej, 5/6 III 1790, Biblioteka Czartoryskich w Krakowie [dalej: $\mathrm{BCz}$ ], rkps 3972, s. 481.

25 Tommaso Antici do K. Ghigiottiego, 13 XII 1789, 17 II, 20 II 1790, AGAD, AGhig. nr 25a, t. VI, k. 127, 139-141. Wcześniej Poniatowski zatrzymał się w Rzymie 7/8 XII 1789 w drodze do Neapolu. Por. A. S ołty s, op. cit., s. 69-70. Opis pobytu w Rzymie między 13 II a ok. 9 VI 1790 na s. 79-102. 
rzenia całkowicie krajowej hierarchii kościelnej i podporządkowania sobie zakonów. Niemniej Saluzzo dostrzegł w wizycie prymasa możliwość forsowania w stosunku do polskiego Kościoła papieskich dezyderatów, takich jak np. awans wzorowego dziekana krakowskiego, ks. Michała Sołtyka ${ }^{26}$.

We wrześniu roku 1790 Poniatowski wyruszył na północ. W połowie października przybył do Paryża. Zastał tam bratanicę, Marię Teresę Tyszkiewiczowa, do której miał goracy uczuciowy stosunek ${ }^{27}$. Listy pisane do niej, a także te skierowane do ks. Żórawskiego, $z$ kolejnego etapu podroży - do Anglii, dają wgląd zarówno w jego stosunek do Rewolucji Francuskiej, jak i do jej kontrwzorca Wielkiej Brytanii. Uważał, że zabór własności kościelnej przez państwo bynajmniej nie rozwiazał finansowego kryzysu Francji. Przewidział „linquietude et La Rage, qui augmenterait à mesure qu'on epuisera Les ressources des assignats et Biens ecclesiastiques qu'il faudra remplaçer par de nouveaux depouille-ments, et finalment toujour par des Surcharges, que personne n'aimera a Suporter"28. Traktowanie rodziny królewskiej przez rewolucjonistów oburzyło go - wydawało mu się „bien plus Cruel, que tous çe qui a Jamais été mis Sur Le Compte de Inquisition d'Espagne"29. Obwiniał za to głównie filozofów: „Vojez a quels exçes de folies et malheurs Les philosophes ont reduit La France entiere" 30 , i ostrzegał ukochana bratanice przed „Irreligion parfaite, qui cause tant de maux a La France"31.

Prymasa zafrapował także szacunek, jakim otaczano wygnanych biskupów francuskich w protestanckiej Anglii, skoro pisał o „Cette Calamité publique des pauvres eveques (auquels l'on accorde en Angleterre toute la Consideration et le Respect, que merite leurs Conduite)"32. Ponadto zazdrościł duchownym anglikańskim ich znacznych i punktualnie wypłacanych dziesięcin, "choć się po nocach, mrozach i złych drogach tłuc nie musza do chorych, ani w zim-

${ }^{26}$ Francesco Maria Saluzzo do kardynała Francesco Zelady, 14 X, 9 XII 1789, Archivio Segreto Vaticano, Archivio della Nunziatura a Varsavia [dalej: ASV, ANV] 66, k. 287-288, 298; T. Antici do K. Żórawskiego, 24 IV 1790, AMS Poniatowski, A I $25, \mathrm{k} .52$.

27 A. S ołt y s, op. cit., s. 114-119.

28 MJP do MTT, 15 II 1791, AGAD, AJP nr 1066, s. 128-129.

${ }^{29}$ MJP do MTT, 1 IV 1791, ibidem, s. 95.

30 MJP do MTT, 17 XII 1790, ibidem, s. 100.

31 MJP do MTT, 3 I 1791, ibidem, s. 60.

32 MJP do MTT, 12/13 I 1791, ibidem, s. 53. 
nych Konsfessyonałach tak iak nasi zdrowie tracić nie sa zobowiązani”. Generalnie uważał, że „Francyi przykład nie do nasladowania; bo iak w Anglij wszystko w naywyższym kwitnie stopniu, tak we Francyi wszystko się ruinuje, kiedy ledwie imię Religij zachowane, a na cudzey własnosci przemijacey iak błyskawica ratunek zasadzony"33.

Głośne dzieło Edmunda Burke'a Reflections on the Revolution in France zysało jego uznanie: „Malgré plusieurs defauts et quelques puerilités Si l'un peut apeler ainsi des extases d'un vieux hom[m]e et quelques erreurs de l'ouvrage de Burke, Il i à de grands beautés et veritées dans son livre et des pensées qui echappent a La premiere lecture". Zgodnie $z$ wykładnią Burke’a (którego poznał podczas pobytu w Anglii ${ }^{34}$ ) prymas przeciwstawiał „liberté tiranique” Francuzów „La liberté Anglaise fondé sur de bonnes Constitutions, balançées par differents pouvoirs". Wierzył nawet, że gdyby Szczęsny Potocki tylko zadał sobie trud poznania zasad ustroju brytyjskiego przez lekture dzieł Considerations on the Laws of England Williama Blackstone'a, De la constitution de l'Angleterre Jeana de Lolme'a i The Wealth of Nations Adama Smitha (w przekładzie Condorceta), mógłby zrozumieć, że ten „Pais Curieux” zamieszkali ludzie, którzy, mimo wszystkich swoich wad - będących wynikiem ich bogactw „sont eclairées laborieux et actif, paraissant plus assuré de Leurs proprietées et liberté que dans les autre païs de l'Europe"35. Było to porównanie podobne do czynionego ówcześnie przez Stanisława Augusta ${ }^{36}$. Prymas dostrzegł i docenił w Anglii zasadę podziału władz oraz spokojne zażywanie własności i wolności przez obywateli. Zatem możemy skonstatować, że również wolał monarchię ograniczona od absolutnej37.

Tymczasem przegrupowanie polityczne, które dokonało się podczas jego nieobecności w Polsce, umożliwiło Stanisławowi Augustowi opracowanie formy rząu, opartej na monteskiuszowskim podziale władz, która zbliżała się do brytyjskiej monarchii ograni-

33 „Excerpt $\mathrm{z}$ listu Xcia Jmci Prymasa pisanego $z$ Londynu do X. Żórawskiego de $1^{\text {ma }}$ Martii 1791, AMS Poniatowski, A I 24, f. 154.

${ }^{34} \mathrm{Z}$. Li b is z ow s k a, Życie polskie..., s. 177.

35 MJP do MTT, 15 II 1791, AGAD, AJP nr 1066, s. 128-131.

36 Por. SA do Filippo Mazzeiego, 25 V 1790, cyt. najpełniej w: R. B u t te r wick, Poland's Last King and English Culture: Stanisław August Poniatowski 1732-1798, Oxford 1998, s. 272-273.

37 Por. zdanie A. S ołtys, op. cit., s. 41, że prymas marzył o absolutyzmie monarszym. 
czonej i parlamentarnej oraz amerykańskiego systemu prezydenckiego ${ }^{38}$. Wiadomość o uchwaleniu Konstytucji 3 maja zastała Michała Poniatowskiego w Anglii.

Nie zajmuję się tutaj debata, wywołana postanowieniem Ustawy Rzadowej, że prymas miał być członkiem Straży w dwojakiej roli: jako „głowa duchowieństwa” i jako prezes Komisji Edukacji Narodowej39. Aczkolwiek nuncjusz apostolski i - być może - niektórzy inni duchowni obawiali się, że prymas mógłby pretendować do władzy należnej Stolicy Apostolskiej, zakonom i innym biskupom, brak było śladu takich ambicji u przebywajaccego w Albionie Poniatowskiego.

Po przeprowadzeniu rewolucji trzeciomajowej, król pragnął powrotu brata i odegrania przez niego wiodacej roli politycznej. „Tous vos amis sont d'avis que vous devenez point tarder a revenir prendre votre place dans le Conseil", pisał 25 maja. Ponadto biskup krakowski Feliks Turski $z$ niechęcia zgodził się zastępować prymasa w Straży Praw, gdyż był zajęty własnymi sprawami gospodarskimi przy obejmowaniu nowej diecezji ${ }^{40}$. Stanisław August ponowił apel o powrót po rezygnacji Ignacego Potockiego i podkanclerzego litewskiego Joachima Chreptowicza $z$ Komisji Edukacji Narodowej. Wyjaśniał bratu, że zasada niełączenia stanowisk w Straży i komisjach rządowych nie dotyczyła go, ponieważ prymas nie mógł kontrasygnować zarządzeń króla. Michał Poniatowski najwidoczniej zamierzał pozostać w Anglii dłużej, ale zgodził się powrócić do Polski ${ }^{41}$. Zasygnalizował również królowi swoje poparcie dla Konstytucji i gotowość współpracy z Ignacym Potockim i Stanisławem Małachowskim $^{42}$.

To pojednanie ułatwiło stosunki towarzyskie, jakie prymas utrzymywał w Londynie $z$ Izabella i Adamem Jerzym Czartoryskimi. W obcym kraju, dawne urazy traciły nieco na znaczeniu. Jak świad-

38 Por. E. Ros tw or ow s ki, Ostatni król Rzeczypospolitej. Geneza i upadek Konstytucji 3 maja, Warszawa 1966, s. 212-215; R. B u t t e rw i c k, Poland's Last King..., s. 285-309.

39 Por. A. J o b e r t, La Commission d'Éducation Nationale en Pologne (17731794). Son oeuvre d'instruction civique, Paris 1941, s. 413; J. W o j a k ow s ki, Straż Praw, Warszawa 1982, s. 73-74.

40 „Tous vos amis sont d'avis que vous devenez point tarder a revenir prendre votre place dans le Conseil". Por. SA do MJP, 25 V 1791, AGAD, AGhig. nr 801b, t. I, k. 177.

41 SA do MJP, 8 VI 1791, ibidem, k. 183-184.

42 SA do A. Debolego, 3 VIII 1791, AGAD, ZP nr 413, k. 157. 
czy list pisany do bratanicy, Poniatowski pozostawał pod wielkim wrażeniem młodzieńca i żywił nadzieję na trwałą z nim przyjaźń: „La princesse generale Sera probablement partie avec Son Fils que Je Vous prie d'embrasser aussi de ma part s'il i'est encore et que J'espere retrouver un ami en Lui en Pologne. Com[m]e Je Suis extremement porté a étre Le Sien, parce qu'Il me parait aimer Sincerement Notre Patrie et qu'il aimera avec Jugement"43.

Michał Poniatowski powrócił do Warszawy około 20 sierpnia 1791 r. i spędził kilka dni $z$ królem w Łazienkach. Mieli wiele do omówienia ${ }^{4}$. Pierwsze tygodnie po powrocie prymasa wróżyły dobrze harmonijnym stosunkom między nim a przywódcami sejmowymi. Nowy poseł francuski, Marie-Louis Descorches, donosił, że chociaż wielu oczekiwało czego innego, „les propos publics de M. le Primat, à ce qu'on m'assûre, ont été tous jusqu'à présent favorables au nouvel ordre des choses"45.

15 września sejm wznowił posiedzenia. Zainteresowanie przemówieniem prymasa było ogromne ${ }^{46}$. Poniatowski deklarował swoje poparcie dla Konstytucji, będąc pod wrażeniem tego, w jakim stopniu podniosła ona prestiż Rzeczypospolitej za granica: „Chlubno było pokazać się Polakiem, słysząc uwielbienie i poważanie powszechne imienia Polskiego”. Wygłaszając $z$ „kościelnym akcentem” paradygmatyczny już dyskurs o „rządnej wolności”, przeciwstawiał „przemoc, arbitralność, spustoszenie Kraiu, i haniebne uleganie" w czasach przed Konstytucja, $z$ równościa, bezpieczeństwem własności i szanowanym rządem, z których Polska cieszyła się teraz. Ponadto, ciagnął prymas, „taka wolność iest darem Niebos. Ten dar dobrotliwey ręki Boskiey uznaię ia nad naszą Rzeczapospolita; znak to, że Naród Polski był ieszcze miły Bogu, Naród zawsze prawowierny, i nieprześladowniczy; Naród, który wydał tylu Mę-

43 MJP do MTT, Londyn, 29 I 1791, AGAD, AJP nr 1066, s. 43. Por. A. S o 1 ty s, op. cit., s. 124-128 (na s. 128 krótszy cytat w przekładzie polskim); Z. G o łę b i o w s ka, W kregu Czartoryskich. Wpływy angielskie w Puławach na przełomie XVIII i XIX wieku, Lublin 2000, s. 53-70.

44 F.M. Saluzzo do F. Zelady, 24 VIII 1791, ASV, ANV 67, k. 101-102; Jean Alexandre Bonneau do A. de Montmorina, 20 VIII 1791, AMAE, CP Pologne 318, depesza 40, k. 420; „Gazeta Narodowa i Obca” [dalej: GNiO], nr 68, 24 VIII 1791.

45 Marie-Louis Descorches do A. de Montmorina, 7 IX 1791, AMAE, CP Pologne 318, depesza 11, k. 447. Por. też Dyplomaci francuscy o Konstytucji 3 maja, wyd. H. Kocój, Kraków 2009, s. 172-173. Korzystając z tego i innych wydawnictw źródłowych prof. Kocója, trzeba także sprawdzić oryginały.

46 M.-L. Descorches do A. de Montmorina, 21 IX 1791, AMAE, CP Pologne 318, depesza 13, k. 464. Por. też Dyplomaci francuscy..., s. 175-177. 
żow cnota, Religia, Obywatelstwem, i obroną Oyczyzny znakomitych. Jeżeli za bliższych czasow pasmo nieszczęść otoczywszy Oyczyznę, do upadku ią nachyliło, tedy Bóg probuiąc iednych cnoty, karzac przewinienia drugich, przez powstanie świetniejszy w czasie chciał uczynić Narod. Już Duchowieństwo wypełniło obowiązki swoie zalecaiac po Świątyniach modly dziękczynienia; to Duchowieństwo, które nigdy Oyczyznie, Królowi i Rzeczypospolitey w wierności, gorliwości, i przywiązaniu niechybiło; które złożone $z$ Braci waszych szanowny Stanie Rycerski, nie raz przykry los Oyczyzny $z$ wami dzieliło".

Chwaliwszy Opatrzność Boska, zauważył, że jest praca do wykonania. Trzeba będzie wiele czasu i starań dla kodyfikacji praw (jego ostrożne rady $\mathrm{w}$ tym punkcie były zgodne $\mathrm{z}$ prośbami nuncjusza) i proponował skoncentrowanie się na konsolidacji rządu i jego finansów, zgodnie wszakże $z$ zasadami sprawiedliwości. Był gotów do pomocy w miarę swoich możliwości ${ }^{47}$.

Jednak miesiąc miodowy nie trwał długo. Próba Poniatowskiego wprowadzenia zebrań towarzyskich w stylu włoskim nie odniosła natychmiastowego sukcesu: „Xże Prymas otworzył u siebie włoskim zwyczaiem assamble w Piatek pod nazwiskiem konwersacye, na których to assamblach wolno do sytości konwersować, ale nic jeść ani pić niemożna, bo nic niedaia; niebarzo ieszcze przyuczeni nasi Polacy do Włoszczyzny, prętko takowe konczą Konwersacye”. Na razie warszawska elita towarzyska wolała wino węgierskie od lemoniady 48 . Ale nie miałoby to żadnego znaczenia, gdyby prymas nie $z$ decydował się na konfrontację $z$ jedna $z$ głównych linii polityki stronnictwa „patriotycznego”.

$\mathrm{Ku}$ zdumieniu niektórych obserwatorów, przez cała jesień 1791 r. Poniatowski atakował projekt zlicytowania królewszczyzn. Pomysł ten został wysunięty w broszurze ks. Michała Ossowskiego O pomnożeniu dochodów publicznych, wydanej na początku 1789 r., i propagowanej na łamach „Pamiętnika Historyczno-Polityczno-Ekonomicznego”. Konsolidacja stronnictwa „patriotycznego” i wzrost wpływów ks. Kołłątaja w ciągu roku 1791 stwarzały szansę na jego urzeczywistnienie. Formalny projekt został przedstawiony sejmowi 10 października 1791 r. Przewidywał sprzedaż królewszczyzn w ciagu pięciu lat oraz emisję przez skarb „biletów” o wartości do

47 Głos... prymasa... 15. września, roku 1791...

48 Gazetka pisana, 19 X 1791, Biblioteka Narodowa [dalej: BN], Akc. 9830, k. 15-16. 
trzech milionów złotych rocznie, w oczekiwaniu przyszłych płatności ${ }^{49}$.

28 października, dzień po wznowieniu projektu przez posła krakowskiego Stanisława Sołtyka, prymas ubolewał nad nieszczęściem obywatela, który ze względów sumienia znalazł się w mniejszości. Dowodził, że należy przynajmniej dochować wiary obecnym posiadaczom królewszczyzn, natomiast dochody $z$ wakujących starostw i większe podatki nałożone na Żydów mogłyby dać tyle samo co sprzedaż, która wymagałaby kosztownej lustracji. Losy sprzedaży dóbr Kościoła we Francji i asygnat Neckera były według niego przestroga przed oparciem pieniądza papierowego na przychodach z królewszczyzn ${ }^{50}$. Poniatowski wydrukował to przemówienie i zarejestrował je w aktach grodzkich warszawskich, celem podkreślenia wagi swojego protestu51.

Niemniej, antyarystokratyczna i antymoskiewska retoryka utrudniały obronę starostw. Ksiądz Kołłątaj i jego zwolennicy wprowadzili dodatki, aby do sprzedaży dóbr przystapiono niezwłocznie, chociaż wycofali wniosek w sprawie pieniądza papierowego. Stanisław Sołtyk podkreślał, że bez tej sprzedaży nieuniknione staną się wyższe podatki ${ }^{2}$. W połowie listopada, biskup chełmski i lubelski Wojciech Skarszewski, w bardziej umiarkowany sposób, apelował do Stanów, aby nie zdradzały obecnych posiadaczy i nie sprzedawały po-

49 W. S m ole ń s ki, Ostatni rok Sejmu Wielkiego, Poznań 2006, s. 131-133; B. de Caché do W.A. v. Kaunitza, 29 X 1791, HHStA, Polen II 53, depesza 827, k. 204. Por. też Austria wobec Konstytucji 3 maja $w$ świetle relacji posła austriackiego Benedykta de Cachégo, wyd. H. Kocój, Kraków 2007, s. 130-131; M. O s s o ws k i, O pomnożeniu dochodów publicznych. Wynalezienie kapitału publicznego ku zasileniu nowych potrzeb Rzeczypospolitey z oszczędzeniem podatków, Warszawa 1789. Rozprawa A. S t r o y n o w s k i e g o, Reforma królewszczyzn na Sejmie Czteroletnim, „Acta Universitatis Lodziensis”, ser. 1, Nauki Humanistyczno-Społeczne 69, 1979, zawiera zadziwiająco precyzyjna, lecz schematyczną klasyfikację zwolenników i przeciwników tej reformy jako postępowców i wsteczników. O roli kręgu Kołłątaja por. M. P a s z to r, Hugo Kołłataj na Sejmie Wielkim w latach 17911792, Warszawa 1991, s. 173-183. W kwestiach fiskalnych por. R. Ry b a rs ki, Skarbowość Polski $w$ dobie rozbiorów, Kraków 1937, s. 345-354.

50 Głos... prymasa... 28. października, 1791 roku, w nieprzytomności Króla miany: „Zydow nawet prawieśmy ieszcze nietknięli. Gdyby to tylko do Skarbu oddawali, co starszyna $z$ nich ździera, iużby się znacznie Skarby pomnożył".

51 Gazetki pisane, 29 X, 3 XI 1791, BN, Akc. 9830, k. 21-24.

52 Gazetka pisana, 15 XI 1791, BPAU, rkps 993, k. 384. 21 XII 1791 B. de Caché napisał do W.A. v. Kaunitza, że starostów nazywano „Aristocraten”, HHStA, Polen II 54, depesza 842, k. 101-102. Por. też Austria wobec Konstytucji 3 maja..., s. 152-154; M. Pa s zto r, op. cit., s. 177-181. 
chopnie cennych gruntów, kiedy można oczekiwać wzrostu ich cen ${ }^{53}$. Dobrze rozumiano, że prymas i niektórzy biskupi obawiali się, że naglace potrzeby fiskalne mogłyby wkrótce sprowokować żądania zabrania również dóbr kościelnych. Broniąc starostw, bronili więc bastionów Kościoła ${ }^{54}$.

Poniatowski jeszcze gwałtowniej zaatakował projekt 5 grudnia, powtarzając, że „przeraża mnie boiaźń, i niezmierna trwoga, abyśmy się mniey baczni nieprzysuwali pod fatalne światło latarniowe, którym Francuzi promienie Religii, honoru, i rozsądku gasić usiłuia w chimerycznym Tłumaczeniu Praw Człowieka, i zupełney rowności, kładąc na iedney szali, Zyda, Kata, Chłopa, Bisurmana, Szlachcica, Mieszczanina i Kapłana, tego tylko tak daleko wyłączywszy z pod opieki Rządowey, że codzień czytamy bezkarnie ranionych, ćwiczonych Kapłanow, i Mniszki, które całe życie poświęciły na wspomożenie nędzy, tegoż rozhukanego ludu. Takie widoki nie moga obiecywać szczęścia żadnemu Kraiowi..."55

Ta gwałtowna krytyka projektu i potępienie Rewolucji Francuskiej, w której usiłował wywrócić metaforę „lumières”, została opublikowana w tłumaczeniu francuskim dla zwiększenia efektu. Descorches i sekretarz poselstwa Jean Alexandre Bonneau byli przerażeni ${ }^{56}$. Oprócz uzyskania poparcia nuncjusza, Poniatowski przesłał kopie kardynałowi Anticiemu i kardynałowi-protektorowi Polski w Rzymie, Giovanniemu Albaniemu ${ }^{57}$.

19 grudnia prymas stoczył ostatni bój w sejmie, obierając za dewizę swojego wystapienia zasadę „nie czyń drugiemu, czego sobie

53 Głos... Woyciecha Skarszewskiego biskupa chetmskiego i lubelskiego o królewszczyznach... 14. listopada r. 1791... Po raz wtóry Skarszewski apelował o uszanowanie świętej zasady własności 9 XII 1791, Diariusz, AGAD, Archiwum Sejmu Czteroletniego [dalej: ASC] nr 9, k. 660-662.

54 B. de Caché do W.A. v. Kaunitza, 19 XI, 7 XII, 17 XII 1791, HHStA, Polen II 54, depesze 833, 838, 841, k. 41, 68, 93-94. Por. też Austria wobec Konstytucji 3 maja..., s. 138-139, 144-146, 150-152; F.M. Saluzzo do F. Zelady, 14 XII, 21 XII 1791, ASV, ANV 67, k. 123-125.

55 Gtos... prymasa na sessyi seymowey $w$ Warszawie dnia 5. grudnia, 1791...

56 J.A. Bonneau do A. de Montmorina, 7 i 10 XII 91, AMAE, CP Pologne 318, depesza 54, k. 594-595. Por. też Dyplomaci francuscy..., s. 91, przyp. 56; M.-L. Descorches do Antoine'a de Lessarta, 31 XII 1791, AMAE, CP Pologne 318, depesza 30, k. 633. Por. też Dyplomaci francuscy..., s. 202-203, 242-244. Wątek antyfrancuski pominęła w swojej relacji GNiO, 7 XII 1791, nie podchwyciła go również „Gazeta Warszawska” ks. Stefana Luskiny.

57 F.M. Saluzzo do F. Zelady, 14 XII 1791, ASV, ANV 67, k. 123-124; MJP do K. Ghigiottiego, 14 XII, 17 XII 1791, AGAD, AGhig. nr 515a, t. II, k. 97, 98. 
nie życzysz". Moralność wymagała szacunku dla cudzej własności. Stare prawa, akt konfederacji i Konstytucja 3 maja gwarantowały bezpieczeństwo mienia wszystkim obywatelom, nie mógł więc zgodzić się na wyraźne nadużycie zaufania publicznego. Już nawet nie chciał przystać na stopniowa sprzedaż królewszczyzn według zasady salvis modernis possessoribus ${ }^{58}$.

Na próżno. Prymas przemawiał podczas głosowania nad dwoma projektami: jednym, przewidującym natychmiastowa sprzedaż starostw, $z$ wypłata rekompensaty starostom; drugim - tylko po śmierci aktualnych posiadaczy. Aczkolwiek obecni senatorowie i ministrowie poparli drugi projekt (13:31), ogromna większość posłów wolała pierwszy (139:28). Zwycięzcom przewodzili posłowie Stanisław Potocki, Kazimierz Rzewuski i Stanisław Sołtyk, a z ministerium Ignacy Potocki, Hugo Kołłataj, marszałek nadworny litewski Stanisław Sołtan i podskarbi nadworny koronny Tomasz Ostrowski59. Jednak sejm uchwalił ustawę dopiero 24 kwietnia 1792 r. Nie starczyło czasu na wprowadzenie jej w życie ${ }^{60}$.

Po podjęciu decyzji 19 grudnia 1791 r., jeden $z$ powyższych ministrów powiedział pewnej rozgniewanej starościnie, że nie powinna się dziwić: wielu starostów, którzy sprzeciwiali się temu postanowieniu, poprzednio popierało konfiskatę majątków biskupich. Autor gazetki pisanej komentował: „Z Tey Ministra Odpowiedzi można wnosić, iż y Intryga Duchownych niemało wpływała do Skassowania Starostw odwdzięczaiąc Skassowania Dobr Biskupich"61. Jednakże, oprócz Poniatowskiego i Skarszewskiego, również biskup inflancki Józef Kossakowski sprzeciwiał się sprzedaży dóbr królewskich. W początkach roku 1789 biskup smoleński Adam Naruszewicz i biskup płocki Krzysztof Hilary Szembek dobitnie wyrazili swój sprzeciw wobec tego pomysłu. Biskup kujawski Józef Rybiński zaproponował 12 grudnia 1791 r. kompromisowy projekt utrzymujaccy dzierżawy. Żaden biskup nie przemówił za licytacja królewszczyzn i wszyscy hierarchowie, którzy byli obecni w sejmie

58 Glos... prymasa in primo turno... 19. grudnia, $1791 \ldots$

59 Karta od głosowania dla senatu: AGAD, ASC nr 9, k. 739-740, dla Stanu Rycerskiego: ASC nr 9, k. 749-757; B. de Caché do W.A. v. Kaunitza, 21 XII 1791, HHStA, Polen II 54, depesza 842, k. 100-101. Por. też Austria wobec Konstytucji 3 maja..., s. 152-154.

60 R. Ry ba r s ki, op. cit., s. 353-354, 456-458; A. St r o y n ow s ki, op. cit., s. 58-59, 61-80; M. Pa s zto r, op. cit., s. 181-183; Urzadzenie wieczyste królewszczyzn, [w:] Volumina legum [dalej: Vol. leg.], t. IX, Kraków 1889, s. 424-437.

61 Gazetka pisana, 27 XII 1791, BPAU, rkps 993, k. 391. 
19 grudnia 1791 r., głosowali przeciw ich natychmiastowej sprzedaży. Prymas bynajmniej nie był izolowany w episkopacie, aczkolwiek nie wszyscy biskupi traktowali obronę starostów jako priorytet62. „Intryga Duchownych” musiała więc dotyczyć księży Kołłątaja i Ossowskiego.

Sprzeciw prymasa wobec projektu był konsekwentny i pryncypialny, wsparty na jego odmowie zgody na arbitralna konfiskatę majątków, nader krytycznym stanowisku wobec Rewolucji Francuskiej, jak również jego ocenie skutków ekonomicznych. Był bowiem przekonany, że zasoby, skonfiskowane Kościołowi we Francji przez rewolucjonistów, wkrótce się wyczerpią i że w efekcie nastąpią dalsze grabieże i podatki ${ }^{63}$. Poseł brytyjski Daniel Hailes potraktował argumenty Poniatowskiego poważnie: „...as they contain an exposure of the principal objections to the measure, it would be superfluous for me to enlarge upon it, any more than to observe that it is to be apprehended that this sort of legal dispossession and alteration of private property (the idea of which seems to have originated in the resumption by Government of the Lands of the Clergy in France) may occasion a great deal of discontent [...] and that too without relieving materially the exigencies of the public Treasure"64. Historycy finansów publicznych oceniali krytycznie prawdopodobne skutki fiskalne, finansowe i gospodarcze tej reformy, gdyby została wdrożona ${ }^{65}$.

62 E. Zi ółek, Biskupi Senatorowie wobec reform Sejmu Czteroletniego, Lublin 2002, s. 177-189; A. St r o y n ow s ki, op. cit., s. 49. Biskupi, którzy wzięli udział w głosowaniu to: Poniatowski, Szembek, Naruszewicz, biskup żmudzki Stefan Giedroyć, Skarszewski, biskup kijowski Cieciszowski, Kossakowski i metropolita unicki Teodozy Rostocki. Por. AGAD, ASC nr 9, k. 739.

63 MJP do K. Ghigiottiego, 30 IX 1791, AGAD, AGhig. nr 515a, t. II, k. 91. Por. MJP do MTT, 15 II 1791, przyp. 28 wyżej, oraz niedatowany list (,jeudi matin”) MJP do MTT, AGAD, AJP nr 1066, k. 136: „La misere qui augmentera à mesure qu'on aura Consomé La Ressourçe des assignats et des Biens ecclesiastiques".

64 Daniel Hailes do hr. Grenville'a, 24 XII 1791, National Archives w Londynie, Kew, Foreign Office [dalej: NA FO] 62/4, depesza 29, k. 321-322, z francuskimi przekładami dwóch przemówień prymasa na k. 323-326. Por. B. de Caché do W.A. v. Kaunitza, 24 XII 1791, HHStA, Polen II 54, depesza 843, k. 115-119. Por. też Austria wobec Konstytucji 3 maja..., s. 155-156; F.M. Saluzzo do F. Zelady, 21 XII 1791, ASV, ANV 67, k. 125.

65 R. Ry ba rski, op. cit., s. 352-354; M. D r o zd ow s ki, Podstawy finansowe działalności państwowej w Polsce 1764-1795, Warszawa-Poznań 1975, s. 139, 163-164. 
Ogólnie uważano, że król popierał ustawę. Mówiono o rozdźwięku między oboma braćmi, a nawet o próbie prymasa stanięcia na czele „eine Mittel=Parteÿ"66. Prymas miał serdecznie dość „Cette Diette eternelle”67. Skarżył się ks. Ghigiottiemu na „La Cabale Infernale" i miał pretensje, że Pius Kiciński, szef gabinetu królewskiego, niedawno wyniesiony przez króla na kasztelanię połaniecka, „a eu l'Impertinence de me Combattre avec des Sophismes et Il sera paye pour Cela par son maitre"68. Jednak Stanisław August nie zajał jasnego stanowiska. Pozwalał niektórym wierzyć, że popiera projekt, jednocześnie dając innym do zrozumienia, że ma doń istotne zastrzeżenia. Już w czerwcu roku 1791 pisał do swojego brata o gwałtownym ataku na sejmie na starostów, co doprowadziło go do publicznego zganienia niesprawiedliwości takich zasad i wskazania wynikłych $z$ tego nieszczęść we Francji69. Podczas debat w połowie listopada roku 1791, król sprzeciwił się sprzedaży królewskich dóbr stołowych wraz $z$ królewszczyznami, wyjaśniajacc, że nie chce dać elektorowi saskiemu powodu do odrzucenia następstwa tronu ${ }^{70}$. Sązono, że monarcha obawiał się, że wyprzedaż królewszczyzn bez odszkodowania niepotrzebnie powiększy liczbę malkontentów (kilka starościn oświadczyło, że nie stać ich na kupno diamentów i stosownie zbojkotowało przyjęcie noworoczne u króla). W dniu głosowania król był nieobecny ${ }^{71}$.

Prymas poniósł porażkę. Wkrótce po głosowaniu Saluzzo znalazł go „molto afflitto e scoragiatto” 72 . Ale pomimo przygnębienia i widocznego napięcia w stosunkach ze Stanisławem Augustem, Michał Poniatowski nie zrezygnował $\mathrm{z}$ zaangażowania w sprawy sta-

66 James Durno do hr. Grenville'a, 30 X 1791, NA FO 62/4, k. 301; B. de Caché do W.A. v. Kaunitza, 29 X 1791, HHStA, Polen II 53, depesza 827, k. 204-205 (cytat). Por. też Austria wobec Konstytucji 3 maja..., s. 130-131; M.-L. Descorches do A. de Lessarta, 31 XII 1791, AMAE, CP Pologne 318, depesza 30, k. 633-635. Por. też Dyplomaci francuscy..., s. 202-203.

${ }_{67}$ MJP do K. Ghigiottiego, 7 XII 1791, AGAD, AGhig. nr 515a, t. II, k. 94.

68 MJP do K. Ghigiottiego, 14 XII 1791, ibidem, k. 97.

69 Atakowi przewodził poseł poznański Ignacy Wyssogota Zakrzewski. Por. SA do MJP, 11 VI 1791, AGAD, AGhig. nr 801b, t. I, k. 185.

70 SA do A. Debolego, 12 XI 1791, AGAD, ZP nr 413, k. 234-235; A. S t r o y now s ki, op. cit., s. 44.

71 B. de Caché do W.A. v. Kaunitza, 21 XII 1791, HHStA, Polen II 54, depesza 842, k. 100. Por. też Austria wobec Konstytucji 3 maja..., s. 152-154; F. S c h u 1 z, Podróże Inflantczyka z Rygi do Warszawy i po Polsce w latach 1791-1793, przekł. J.I. Kraszewski, oprac. W. Zawadzki, Warszawa 1956, s. 231-232.

72 F.M. Saluzzo do F. Zelady, 21 XII 1791, ASV, ANV 67, k. 125. 
rostw, przenoszac je na sejmiki lutowe roku 1792, wraz ze sprawa cenzury duchownej73. Zanim przystapimy do analizy tych starań, rozpatrzymy jego stosunki $z$ posłem rewolucyjnej Francji w Warszawie.

Stosunki polsko-francuskie za panowania Stanisława Augusta były utrzymane na nader niskiej dyplomatycznej randze aż do końca lat osiemdziesiatych XVIII w. Aczkolwiek sejm przestał się liczyć $z$ obiekcjami Petersburga wobec podniesienia tej rangi jesienią roku 1788, Francja była zbyt pochłonięta sprawami wewnętrznymi, aby nawiązać pełne stosunki dyplomatyczne $z$ Rzeczapospolitą. Dopiero wiosna 1791 r. rząd francuski zdecydował się wysłać ministra plenipotenta nad Wisłę. Po swoim przybyciu do Warszawy w lipcu tego roku, Marie-Louis Descorches nieuchronnie znalazł się $\mathrm{w}$ centrum zainteresowania polskich frankofilów, jak również Francuzów osiadłych w polskiej stolicy, a także innych obcych dyplomatów. Początkowo postępował ostrożnie, dokonując publicznych wystąpień tylko w kontekstach nie budzacych kontrowersji i podejrzeń. Takie były obchody święta św. Ludwika 25 sierpnia w jego parafialnym kościele, celebrowane przez biskupa sufragana warszawskiego Antonina Malinowskiego. Po tym jak Ludwik XVI przyją 13 września 1791 r. nowa Konstytucję, Descorches doprowadził do odśpiewania Te Deum w tymże kościele parafialnym i iluminował swój dom ${ }^{74}$.

Wcześniej Ludwik XVI zapewniał prymasa, iż poseł, markiz de Saint-Croix, został doskonale poinformowany o przywiąaniu króla Francji do niego ${ }^{75}$. Jednak teraz, po nieudanej ucieczce rodziny królewskiej w czerwcu 1791 r., znaczyło to już niewiele. Przybywszy do Warszawy, prymas odkrył $z$ niezadowoleniem, że markiz de Saint-Croix woli nazywać się po prostu Monsieur Descorches i że zaczał utrzymywać stosunki z niektórymi z młodszych „patriotów”. Faktycznie, na czele tych młodych ludzi, którzy według Descorchesa myśleli „filozoficznie”, stali Julian Ursyn Niemcewicz, Józef Weyssenhoff i Tadeusz Mostowski, redaktorzy „Gazety Narodowej

73 Z. Z i e lińs ka, op. cit., s. 465.

74 M.-L. Descorches do A. de Montmorina, 31 VIII 1791, AMAE, CP Pologne 318, depesza 10, k. 438, oraz 3 X 1791, AMAE, CP Pologne 318, depesza 15, k. 475. Por. też Dyplomaci francuscy..., s. 171-172, 178-179; GNiO, 3 IX, 3 X 1791.

75 Ludwik XVI do MJP, Paryż 9 V 1791, Biblioteka Uniwersytetu Jagiellońskiego w Krakowie, rkps 2987, k. 241. Kopia w: AMS Poniatowski, A I 27, s. 25. 
i Obcej”. Wkrótce po swoim przyjeździe Descorches przesłał do Paryża życzliwą relację o nich i o ich publikacji76.

Descorches został przyjęty przez prymasa 15 września 1791 r., a następnie otrzymał od niego „toutes les honnêtetés de société que je pouvois désirer, mais point de visite". Dowiedziawszy się, że Poniatowski złożył wizytę posłowi hiszpańskiemu, Bailly’emu de Cuber, poseł francuski zapytał prymasa czy on również mógłby spodziewać się wizyty. Poniatowski miał odpowiedzieć, że pomimo obowiazującej go etykiety złożył prywatną wizytę z przyjaźni dla Cubera i uczyni to samo dla Descorchesa. Poseł francuski przestał przychodzić do pałacu prymasa i chociaż nadal posyłał tam żonę, to Poniatowski nie zaszczycił go wizyta ${ }^{77}$. Kilka tygodni później, gdy Poniatowski zaprosił Descorchesa na obiad, poseł odpowiedział prymasowi listem, przesyłając mu wyrazy szacunku, ale prosząc również o wyjaśnienie braku wizyty i zwracając się do niego per „Votre Excellence” (jak uczynił to wcześniej w rozmowie). Załączył również kopię depeszy, w której mówił o „pointilleries”. Następnego dnia prymas odpisał, zwracając się do „Monsieur le Marquis”. Wyjaśnił, że zrobił wyjątek dla Cubera, gdyż ten był chory, oświadczył, że był urażony wyrażeniem „pointilleries” i stwierdził, że skoro Descorches uznał za stosowne skonsultować się ze swoim dworem, nie mógł przeoczyć faktu, że poseł nie zwracał się do niego per "Votre Altesse". Dodając, że spodziewa się, że Descorches będzie musiał oczekiwać instrukcji z Paryża, prymas praktycznie zamroził swoje stosunki $z$ posłem francuskim ${ }^{78}$.

76 M.-L. Descorches do A. de Montmorina, 20 VIII 1791, AMAE, CP Pologne 318, depesza 8, k. 422-423. Por. też Dyplomaci francuscy..., s. 168-169.

77 M.-L. Descorches do A. de Montmorina, 21 IX, 26 X 1791, AMAE, CP Pologne 318, depeszy 13 i 19, k. 463, 521-522 (cytat). Por. też Dyplomaci francuscy..., s. 175-177, 185-187.

78 Kopia listu M.-L. Descorchesa do MJP, 14 XI 1791, MJP do M. Descorchesa, 15 XI 1791, AMAE, CP 318, k. 556-557. Kopie w: AMS Poniatowski, A I 27, s. 2728, także w: A I 19, k. 261-263; M.-L. Descorches do A. de Montmorina, 19 XI 1791, AMAE, CP 318, depesza 23, k. 563. Por. też Dyplomaci francuscy..., s. 190192. Z listu posła polskiego w Paryżu, Feliksa Oraczewskiego, do MJP z 2 XII 1791 (AMS Poniatowski, A I 27, s. 28-30) wynika, że po otrzymaniu (nieznalezionego) listu prymasa z 15 XI 1791 postarał się załatwić sprawę tytułu Altesse u Pierre'a Hennina, który prowadził korespondencje polska w Paryżu, bez udania się do nowego ministra. Jednak 6 I 1792 A. de Lessart napisał w instrukcji do Descorchesa, aby nie odmówił pretensji prymasa i szedł $\mathrm{w}$ tej sprawie za przykładem kolegów. Przy tym zastrzegł, że „Les choses pourroient changer si la nouvelle constitution qui a rendu le Royaume hereditaire s'etabliroit et si la Primatie 
Descorches przypisywał większość krytycyzmu Poniatowskiego wobec Rewolucji Francuskiej wspomnianemu sporowi o etykietę79. Jednak prawdopodobnie było odwrotnie. Zapewne Poniatowski był zadowolony $z$ posiadania pretekstu do unikania Descorchesa, gdyż w ten sposób nie dawał do zrozumienia, że aprobuje wydarzenia we Francji. Ten impas także Descorches'owi mógł być na rękę ${ }^{80}$. Poniatowski osobiście widział Rewolucję Francuska jesienią roku 1790. Nie podobała mu się wcale.

Stanisław August, mimo rosnących zastrzeżeń co do tempa zmian, ogólnie sympatyzował z Rewolucja Francuska aż do pierwszych miesięcy roku $1791^{81}$. Do końca tego roku przekonał się jednak, być może częściowo pod wpływem prymasa, że Francuzi osiądą na mieliźnie w sprawie przysięgi duchownych i rosnacej zależności od papierowego pieniądza82. Wiedział, że ościenne dwory łaknęły donosów, iż Polska była wylęgarnia jakobinizmu. $Z$ tej przyczyny, jak również z potrzeby zrobienia wrażenia na szlachcie, pragnął, aby papież pobłogosławił Konstytucji 3 maja oraz, aby wszystkie dwory europejskie brały za dobra monetę kontrast między pokojowa polską rewolucja a gwałtowna Rewolucją francuska, podkreślony m.in. przez Burke'a ${ }^{83}$.

Stanisławowi Augustowi również zależało na tym, aby „antuzyazm" manifestowany wobec Francji przez mieszczan oraz sporadyczne przypadki odmawiania pańszczyzny przez chłopów nie zrażały szlachty do rewolucji trzeciomajowej. Chociaż uniwersały i oddziały wojska szybko wyprowadziły chłopów z błędnego mniemania, że Konstytucja uwolniła ich z poddaństwa, Stanisław August obawiał się, że „malkontenci” rozpowszechniaja pogłoski, jakoby

cessoit d'etre occupé par un frere du Roy actuel". Por. AMAE, CP Pologne 319, k. 5. Spór o Altesse sięgał 1764 r. Por. Z. Z i e liń s k a, op. cit., s. 464.

79 M.-L. Descorches do A. de Lessarta, 21 XII, 31 XII 1791, AMAE, CP Pologne 318, depesze 28, 30, k. 618, 633. Por. też Dyplomaci francuscy..., s. 199-201, 202-203.

80 M.-L. Descorches do A. de Lessarta, 21 XII 1791, AMAE, CP Pologne 318, depesza 28, k. 618-619. Por. też Dyplomaci francuscy..., s. 199-201. Znamienne, że zaraz po relacjonowaniu W.A. v. Kaunitzowi owego sporu o etykietę 17 XII 1791, B. de Caché przeciwstawiał wrogość prymasa wobec Rewolucji Francuskiej „democratische Denkensart" Descorchesa. Por. HHStA, Polen II 54, depesza 842, k. 93-94. Por. też Austria wobec Konstytucji 3 maja..., s. 150-152.

81 Por. J. Michalski, Stanisław August obserwatorem rewolucji francuskiej, [w:] i d e m, Studia historyczne..., t. I, s. 500-514.

82 SA do A. Debolego, 3 XII, 28 XII 1791, AGAD, ZP nr 413, k. 249, 270.

83 Por. Z. Li b is z ow s ka, Edmund Burke a Polska..., passim. 
planował „po Francusku, że chłop będzie zrownany swemu Panu”84. Podobnie jak król, prymas także odczuwał potrzebę zdystansowania się Polski wobec Francji na dworach europejskich. Ich obawy nie były bezpodstawne. Polski poseł w Sztokholmie Jerzy Potocki ostrzegał króla, że decyzja konfiskaty starostw wywołała na dworze szwedzkim niekorzystne skojarzenie $z$ Francja ${ }^{85}$.

Prymas stoczył następną batalię o duchowną cenzurę publikacji, poruszających kwestie religii i moralności. Głos wolny obywatela w sprawach publicznych był zakorzeniony w polskiej kulturze politycznej i począwszy od roku 1609 ubezpieczony prawami. Stopniowo rozszerzono jego zakres na wszystkie formy wypowiedzi. Jednak mało kto przyznałby niczym nieograniczone prawo do pisania przeciw Wierze panujacej lub dobrym obyczajom. Aczkolwiek słabo działała w praktyce, cenzura duchowna dzieł tyczacych religii i moralności miała swoje uznane miejsce w polskiej kulturze politycznej86.

Piąty artykuł czwartego rozdziału ustawy z 17 czerwca 1791 r., ustanawiającej Komisję Policji Obojga Narodów, określał jej zadanie zapewnieniem „ażeby według przepisów, i warunków prawa wolność pisania i drukowania pewną, i nienaruszona była" ${ }^{87}$. Niczego nie mówił o dziełach wymierzonych przeciwko religii lub moralności. Jest rzeczą zrozumiała, że hierarchii kościelnej zależało, aby rząd zaprzeczył wrażeniu, że wszelkie ograniczenia wobec pisarzy i wydawców zostały tym samym zniesione. Prymas zwołał posiedzenie kolegium biskupów 17 stycznia 1792 r. 88

Poniatowski zawczasu kazał przygotować fragmenty $z$ odnośnych ustaw obradujacego sejmu. Pierwszy zawierał jedenaste prawo kardynalne, poddajace pisma na temat religii lub szkodliwe dla moralności cenzurze kościelnej. Następnym był pierwszy artykuł Ustawy Rzadowej: „Religia Narodową Panuiąca iest y będzie Wiara Ś. Rzymska Katolicka ze wszystkiemi iey Prawami”. Po przytoczonej wyżej

84 SA do A. Debolego, 24 VIII 1791, AGAD, ZP nr 413, k. 174-175.

85 H. R z a d k ow s k a, Stosunek polskiej opinii publicznej do Rewolucji Francuskiej, Warszawa 1948, s. 149, przyp. 195.

86 Por. I. Ho mola, Walka o wolność druku w publicystyce polskiej drugiej połowy XVIII wieku, „Przegląd Historyczny” 1960, t. LI, nr 1, s. 74-94; A. G r z e ś k ow ia k-Krwawic z, Dyskusje o wolności słowa $w$ czasach stanisławowskich, „Kwartalnik Historyczny” 1995, t. CII, nr 1, s. 53-65.

87 Vol. leg., t. IX, s. 279.

88 Wzięli w nim udział biskupi: Rybiński, Okęcki, Giedroyć, Skarszewski, Cieciszowski, kamieniecki Adam Krasiński i Kossakowski oraz metropolita Rostocki. 
ustawie o Komisji Policji, cytowano ustawę o Straży Praw, według której „kazda decyzya w Strazy za przeciwna Prawu będzie miana która narusza Konstytucya Rządu Rzpltey, oraz wolność Osoby, wolność mowienia, pisania y drukowania, tudzież wolność majat$\mathrm{ku} " 89$.

Wszyscy obecni biskupi zaaprobowali i podpisali memoriał do króla w Straży. Oświadczyli, że nie potrafia rozdzielić swoich obowiązków jako obywatele i senatorowie od obowiąków jako duszpasterze, zwłaszcza szerzenia Wiary i cnoty, „które sa najtrwalszemi zasadami dobra ojczyzny". Ufali, że króla nie trzeba było przekonywać, „ile czysta i prawdziwa religia jest węgielnym kamieniem trwałości państw i narodów". Jednak ani jego sprawdzona gorliwość, ani ustawy, ani ich własna wytrwałość nie wystarczały do zapobieżenia „okropnym skutkom”, które nieograniczona wolność prasy „prędzej lub później na tę ojczyznę sprowadzić może”.

Tłumaczyli, że te same ustawy, które zapewniały wolność słowa i prasy, zawierały warunek, że pisma „w materiach religii i dziełach ku zepsuciu obyczajów dążących pod duchowna cenzura tudzież aprobacja jurysdykcji duchownej wiary panującej” podpadać maja. Z Praw kard[ynalnych] art. XI". A więc obowiązek Komisji Policji zachowania wolności prasy nie mógł rozciagać się ani na utwory „w kraju bezimiennie drukowane”, ani na przekłady i import utworów zagranicznych, rozpowszechnianych otwarcie lub ukradkiem i które „szyderskim obrotem znieważają świętość i naukę religii, zaszczepiaja natomiast najszkodliwsza truciznę moralności i obyczajów, i powszechnym wylewem zepsucia całej Publiczności zagrażają".

Biskupi z żalem informowali króla, że księgarnie sa pełne takich utworów. „Bluźnierstwa przeciw Bogu, Trójcy Świętej, aniołom, Zbawicielowi i Matce Jego $z$ obrzydliwym wszeteczeństwem połączone, sa największa zaletą pism takich, bezkarnie przedawanych, na które umysł prawowiernych Polaków wzdryga się". Obawiali się, że religia katolicka nie może pozostać panująca, jeżeli może być znieważana bezkarnie. A zatem błagali króla o zapewnienie, aby, zgodnie $z$ prawami kardynalnymi, żadne wydawnictwo nie publikowało utworów na temat religii czy moralności, i żaden księgarz nie importował lub nie sprzedawał takich utworów bez kościelnej aprobaty. W razie nieposłuszeństwa prosili o wsparcie

89 AAG, ACap., B84, k. 301. 
władzy duchownej przez władzę świeckąa ${ }^{90}$. Rodzaj pism, których rozpowszechnianie biskupi szczególnie pragnęli uniemożliwić, wyłania się $\mathrm{z}$ listy antychrześcijańskich utworów, zachowanej w tych dokumentach. Były one w ogromnej większości francuskie i obejmowały: Traité des trois imposteurs (chodzi o Mojżesza, Jezusa i Mahometa), La Bible enfin expliquée par Voltaire i La Pucelle d'Orléans, również Woltera ${ }^{91}$. Nacisk na dzieła importowane i tłumaczone był również jasny dla nuncjusza ${ }^{92}$.

Przygotowano $\mathrm{w}$ kręgu prymasa argumentację za wprowadzeniem cenzury duchownej. Zastrzegając, że nie podaja w wątpliwość poprzednich ustaw, zapewniających kościelna gestię $\mathrm{w}$ zakresie cenzury w sprawach religii i moralności, biskupi odnieśli się tylko do aktów, uchwalonych przez obecny sejm. Pierwszym argumentem było to, że twórcy Konstytucji, gwarantując prawa religii panującej, nie mogli mieć zamiaru, „żeby taż Wiara, Jey zasady, iey Nauki wyszydzenia, pośmiewiska, burzenia, y wzgardy celem były". Drugim, że „warunki” w ustawie, ustanawiającej Komisje Policji były warunkiem praw kardynalnych, przewidujacych cenzurę kościelna w sprawach religii i moralności, które to sprawy tym samym zostały wyłączone $z$ "głosu wolnego", zagwarantowanego na zebraniach publicznych i wolności publikacji utworów pod nazwiskiem autora. Czy żądanie biskupów mogłoby być sprzeczne $z$ Konstytucją 3 maja, która nawet nie wspominała o wolności prasy? Każda ze swobód obywatelskich miała swoje granice, określone prawem. W tym przypadku prawo było jasne a Straż Praw powinna polecić Komisji Policji jego egzekwowanie ${ }^{93}$. W dalszych uwagach biskupi żądali, aby „Juryzdykcye Narodowe” pomagały „władzy koscielney, ilekroć Jey przestrogi, y srzodki duchowne stały by się bezskutecznemi"94.

90 Wydał go Józef Szczepaniec jako aneks 2 do artykułu: $Z$ zagadnień cenzury $w$ Polsce po 3 maja 1791 roku, [w:] Autor, tekst, cenzura. Prace na kongres slawistów $w$ Krakowie $w$ roku 1998, red. J. Pelc i M. Prejs, Warszawa 1998, s. 203-23, a zwłaszcza 228-230. Brulion w: AAG, ACap., B84, k. 255-260, wersja łacińska, zapewne przeznaczona dla Stolicy Apostolskiej w: AAG, ACap., B84, k. 250-253.

91 AAG, ACap., B84, k. 299.

92 Sprawa nie została wzmiankowana w depeszach Saluzzo, mimo że o niej rozmawiał $z$ rezydentem saskim. Franz August Essen do Johanna Adolfa Lossa, 25 II 1792, Loc. 3571, t. XXIX, depesza 10, k. 87-89, wyd. w: Die Verfassung vom 3. Mai 1791 in den Berichten des sächsischen Gesandten Franz Essen, wyd. H. Kocój, Katowice 1999, s. 140-143. Być może Saluzzo poinformował Zeladę inną droga.

93 „Wywód z Praw Krajowych należący do Memoryału [...] Biskupów z 17. Stycznia 1792 Królowi w Straży podanego", AAG, ACap., B84, k. 255-256.

94 AAG, ACap., B84, k. 254. Inny brulion por. ibidem, k. 266. 
Te materiały mogły także posłużyć publicystom, z których pierwszym był ks. Jan Albertrandi. Broszura Albertrandiego, Uwagi nad wolnościa drukowania y sprzedaży ksiag publiczney, została załączona 21 stycznia 1792 r. do „Gazety Warszawskiej”. Została już omówiona w literaturze przedmiotu. Tutaj jedynie zwracam uwage na to, że Albertrandi doceniał nie tylko zagrożenia, ale i korzyści płynące $z$ wolności druku. Konkludował, że hierarchowie kościelni nie mogli zrzec się obowiąku nadzoru nad wszystkim, co jest związane $z$ religia i że powinna im pomagać władza cywilna w karaniu winowajców, zwłaszcza że rząd również „zależał od moralności”95.

Majac przygotowany grunt, 22 stycznia 1792 r. prymas przedstawił Straży memoriał biskupów. Król chwalił biskupów za ich „o nieskazitelność religii panującej i dobrych obyczajów troskliwe baczenie" i poprosił Ignacego Potockiego o opinię. Potocki odpowiedział 2 lutego, że nie jest uprawniony do informowania ani podpisania jakiejkolwiek decyzji $z$ powodu ustawy gwarantujacej wolność prasy, ale widzi potrzebę ustawy ustalającej środki, którymi władza świecka mogłaby wspomagać Kościół w każdym przypadku, gdyby środki duchowe okazały się niewystarczajace. W ten sposób, biorac pod uwagę liczbę spraw czekajacych „na roztrząśnięcie” i decyzję w sejmie, pytanie zostało odłożone na czas nieokreślony ${ }^{96}$. Potockiemu niewątpliwie zależało na uniknięciu wprowadzenia cenzury, ale jednocześnie nie życzył sobie otwartego konfliktu $z$ hierarchia kościelną. Zablokowany w Straży prymas w lutym 1792 r. przeniósł swoją kampanię na sejmiki, ze skromnymi, jak zobaczymy, rezultatami.

Lutowe sejmiki deputackie stały się pewnego rodzaju referendum nad Konstytucja 3 maja. Jak dowodza badania Wojciecha Szczygielskiego, szlachta na prawie trzech czwartych sejmików w całej Rzeczypospolitej dała silny albo bardzo silny wyraz poparcia dla rewolucji trzeciomajowej. Jednakże można jednocześnie stwierdzić, że znaczna część szlacheckiego narodu, zwłaszcza w prowincjach koronnych, miała w dalszym ciagu różne watpliwości wobec treści i sposobu uchwalenia prawa 3 maja. Mniej niż jedna czwarta sej-

$95 \mathrm{~J}$. A 1 b e r tra ndi, Uwagi nad wolnościa drukowania y sprzedaży ksiag publiczney, b.m.d. [Warszawa 1792]. Omówienie tego pisma por. J. S z c z e p a $\mathrm{n}$ i e c, $Z$ zagadnień cenzury, s. 217-219. Por. też A. G r z e ś k o w i a k-K r w a w i c z, op. cit., s. 61, przyp. 51 .

96 J. S z c ze pa n i e c, op. cit., s. 220 (cytat); A. Z a h or s ki, Centralne instytucje policyjne $w$ Polsce $w$ dobie rozbiorów, Warszawa 1959, s. 203; J. W oj a kow s ki, op. cit., s. 194-195. 
mików koronnych wyraziła chęć najsilniejszego poparcia, czyli zaprzysiężenia Konstytucji ${ }^{97}$.

Pomimo katolickich obrzędów i języka, którymi były przesiąknięte czynności i uchwały sejmików, rezydent saski dopatrzył się związku między przypadkami odmowy zaprzysiężenia Konstytucji a wpływem duchowieństwa. Franz August Essen przypisał relacje o niezadowoleniu kleru obawom o krzywoprzysięstwo w następstwie nacisków na składanie przysięgi, ale w tym samym zdaniu pisał o kampanii biskupów przeciw tłumaczeniu i sprzedaży „des livres scandaleux arrivants icy de la France"98. Szczygielski nazywa postawę prymasa wobec referendum „pewnym dysonansem”, a nawet „nieodpowiedzialnościa polityczna”99. Chociaż Wojciech Skarszewski, Ignacy Massalski i Józef Kossakowski byli wrogo nastawieni do Konstytucji, to potraktowanie Michała Poniatowskiego łącznie $z$ nimi byłoby jednak mylące.

Prymas nie zaprzysiagł Konstytucji osobiście. Ale świadectwo pięciopunktowej wzorcowej instrukcji sejmikowej wskazuje na jego poparcie dla rewolucji trzeciomajowej. Pierwszy punkt przywołał szkodliwość interregnów oraz utraty ziem przez Rzeczpospolita i deklarował przekonanie o potrzebie naprawy wad systemu rządów albo raczej przywrócenia tego, co ongiś budziło szacunek Europy do Polaków. A więc posłowie powinni dziękować królowi i Stanom za Ustawe Rzadowa i za przyznanie sukcesji elektorowi saskiemu. Następny punkt krytykował sprzedaż królewszczyzn jako mogąca spowodować spadek cen ziemi, ustanowienie „nowy gatunek Dóbr [...] na kształt zagranicznych Majoratów”, co „wcale Krajowi Republikantskiemu niesłuży”, zwiększanie obciążeń podatkowych gruntów dziedzicznych, a nawet doprowadzić do „zamieszania Krajowego”, dając prawo masom „nieoświeconego ieszcze u Nas Pospólstwa” odwołania się do sądów referendarskich. Trzeci punkt proponował, jako alternatywę wobec sprzedaży, pięćdziesięcioletnią dzierżawę, a czwarty sprzeciwiał się wprowadzeniu papierowego pieniądza. Ostatni punkt instruował posłów, aby żądali „obmyślenia naylepszych sposobów, któremiby nayskuteczniey złączone władze Du-

97 Por. W. S z c zy gi e ls k i, Referendum trzeciomajowe. Sejmiki lutowe 1792 roku, Łódź 1994, s. 394-396 i passim.

98 F.A. Essen do J.A. Lossa, 25 II 1792, Sächsische Hauptstaatsarchiv w Dreźnie, Loc. 3571, t. XXIX, depesza 10, k. 87-88. Por. też Die Verfassung vom 3. Mai $1791 \ldots$, s. $140-143$.

99 W. S z c zy gi e 1s ki, op. cit., s. 29-30. 
chowne i Swieckie zapobiegały szerzacey się pod pretextem źle tłomaczoney wolności druków drukowanie i przedawanie Pism i Książek Wiarę S. obyczaie i uczciwość każące $z$ niepowetowana Szkoda bliźniego i Oyczyzny"100. Podobny obraz wyłania się $z$ jego zachowanej korespondencji. Prosił co najmniej dwa sejmiki o zaprzysiężenie Konstytucji101.

$Z$ ośmiu sejmików, o których wiemy, że żądały cenzury dzieł skierowanych przeciw religii i moralności, sejmiki rożański i zakroczymski milczały w sprawie Konstytucji. Województwo łęczyckie uchwaliło podziękowanie (w „wymownych wyrazach”), natomiast sejmiki pyzdrski, liwski i kijowski „zaręczyły” Konstytucję (czyli złożyły przyrzeczenie zbliżone do przysięgi), a sejmiki sieradzki i piński „jej zaprzysięgły”. Zatem pytamy: czy szlachta tych miejscowości słynęła ze swojej zaciętej wrogości wobec wolnomyślicielstwa i herezji? W przypadku mazowieckich ziem rożańskiej, zakroczymskiej i liwskiej, zamieszkanych przez liczna i zubożała szlachtę, odpowiedzieć można twierdząco. Czynniki wyznaniowe mogły także odegrać rolę $\mathrm{w}$ zachęcaniu do obrony katolicyzmu gdzie indziej. W powiecie pińskim i województwie kijowskim znajdowały się skupiska ludności prawosławnej, natomiast luteranie gęsto zamieszkiwali miasta województwa sieradzkiego, wzdłuż granicy śląskiej. Ale pozostałe sejmiki mazowieckie nie wysuwały tego żądania, podczas gdy zasobny powiat pyzdrski, leżący w sercu Wielkopolski, nie był w żadnym stopniu „zacofany”. W Pyzdrach kluczowa rolę, w imieniu prymasa, odgrywał Józef Radzimiński, wojewoda gnieźnieński, który żądał, podczas debaty nad ustawą o miastach królewskich, pierwszeństwa dla katolików w dostępie do urzędów miejskich ${ }^{102}$. W Pińsku, „głównym sprawca”" był Mateusz Butrymowicz, który niewątpliwie także stał za poleceniem Stanom ojców bazylianów. Podobna rolę odegrał w Łęczycy regalista, poseł Franciszek Jerzmanowski, który systematycznie bronił interesów katolickich i duchownych na sejmie ${ }^{103}$. Oprócz poparcia większości dezyderatów Poniatowskiego (w przypadku cenzury dosłownie powtarzając jego wzór), województwo łęczyckie oświadczyło, że jest „uwe-

100 „Zalecenie Posłom Naszym...”, AAG, ACap., B84, k. 277-278.

101 W. S z c zy gie 1s ki, op. cit., s. 299.

102 J. Radzimiński do MJP, Śrebna Góra 24 II 1792, Biblioteka Uniwersytetu Warszawskiego [dalej: BUW], rkps 136, k. 19-20. Por. diariusz sejmowy z 18 IV 1791, AGAD, ASC nr 17, k. 275-276.

103 Franciszek Jerzmanowski do MJP, Łęczyca 10 II 1792, BUW, rkps 136, k. $7-8$. 
selone Jego szczęśliwym z zagranicy powrotem"104. Szlachta liwska również powtórzyła sformułowania prymasa w sprawie cenzury. Ponadto, obiecała zachować panująca wiarę katolicką „chociażby $z$ azardem majątku i życia”. Sejmik zakończyło Te Deum ${ }^{105}$.

Sejmiki rożański i zakroczymski, które nie uchwaliły dziękczynienia za Konstytucję, wykroczyły poza propozycje prymasa w sprawie cenzury. Laudum rożańskie potępiało książki „pełne lubieżności i fałszywych przeciwko religii maksym", i żądało wygnania tych, którzy je sprzedawali. Ponadto, domagało się grzywny w wysokości 1000 złotych dla wynajmujaccych lokale klubom politycznym. Takie „schadzki z ludzi rozmaitego stanu i religii, zwane klopy, lub innym nazwiskiem, utwarzają oziębłość religii, rozwiązłość myśli, wzgardę starszeństwa"106.

Brać zakroczymska potępiała w podobny sposób kluby polityczne i dodała: „iżby podobieństwem Francyi niedoznaliśmy nieszczęśliwych skutkow”. Żądała: „Książki bez autora bez imienne, gorszace czytających, religii przeciwne rząd i obyczaje psujacce, aby nie były wydawane, ani $z$ zagranicy sprowadzone, lub tłomaczone, wnosić j.w. posłowie będa, iżby zwierzchność duchowna i policye scisły nad tym dozor miały, i podług praw kardynalnych postępujac”. Laudum wyrażało również zaniepokojenie prerogatywami, przyznanymi mieszczanom, w obawie przed dawaniem złego przykładu chłopom i nalegało, aby te prerogatywy nie zostały rozciagnięte na miasta kościelne. Nie od rzeczy będzie wspomnienie o tym, że Józef Radzicki, poseł zakroczymski, przewodził w kwietniu 1791 r. opozycji wobec równego dostępu do urzędów miejskich dla niekatolików107. Dowód w postaci sformułowań sugeruje, że wpływ prymasa był mniej decydujący w Rożanie i Zakroczymiu aniżeli w Łęczycy i Liwie. Powinno to przynajmniej moderować krytykę „nieodpowiedzialności” Poniatowskiego, wygłoszona przez Szczygielskiego. Prymas lojalnie wspierał króla w sprawie zasadniczej, czyli w zabiegach o jak najsilniejsze poparcie szlachty dla Konstytucji. Niemniej trudno ocenić wyniki starań prymasa w sprawach królewszczyzn i cenzury inaczej niż jako porażkę.

104 W. S z c zy g i e $1 \mathrm{~s} \mathrm{k}$ i, op. cit., s. 92-95, 116-122, 154-157, 161-163, 260266, 357-358. Sejmik łęczycki: BPAU, rkps 8330, k. 825. Sejmik piński: AMS Poniatowski, A I 19, k. 105-108 (laudum), k. 123-124 (diariusz).

105 W. S z c z y g i e ls k i, op. cit., s. 116-122; BPAU, rkps 8322, k. 614-620.

106 W. S z c zy gie 1s ki, op. cit., s. 161-162.

107 Ibidem, s. 154-157; BPAU, rkps 8354, k. 344-353. Por. diariusz sejmowy z 18 IV 1791, ASC 17, k. 275-276. 
Pod koniec sejmu prymas usunał się nieco w cień. Martwił się wpływem wywieranym na króla przez Kołłątaja i Scipione Piattolego. Odnosił się sceptycznie do obchodów pierwszej rocznicy uchwalenia Konstytucji108. Król wolał wierzyć, że „taki się okazał duch iedności, y determinacyi" tego dnia, że żaden $z$ krajowych oponentów nie mógł oczekiwać pomocy niesionej przez „przemoc Moskiewska" ${ }^{109}$. Przez rok od uchwalenia Konstytucji odkładał rozpoczęcie negocjacji $z$ dworem petersburskim, wychodząc $z$ założenia, że - o ile nie będzie pretekstu - zbrojnej interwencji nie będzie ${ }^{110}$. Mało prawdopodobne, aby prymas żywił podobne złudzenia. Niemniej jednak, Michał Poniatowski odegrał wybitna rolę w uroczystościach. Pomimo żywionych wątpliwości przyczynił się do otoczenia Konstytucji opatrznościową aurą111.

Wyjeżdżając $z$ Polski we wrześniu roku 1789, Michał Poniatowski nie uczynił niczego, co mogłoby szkodzić pozycji jego brata. Wróciwszy do kraju, prymas dalej wykazywał lojalność wobec Stanisława Augusta i również wobec Polskiej Rewolucji, aż do czasu, kiedy król przystapił do konfederacji targowickiej. Postępował lojalnie pomimo dotkliwych politycznych porażek i narastajacych obaw co do losu Rzeczypospolitej ${ }^{112}$.

Nie dziwi, że w powojennej Polsce krytyczne stanowisko prymasa wobec Rewolucji Francuskiej, jego sprzeciw wobec niby „postępowego" projektu sprzedaży królewszczyzn i starania o ograniczenie wolności druku w sprawach tyczacych religii oraz moralności skłoniły niektórych historyków do zaszufladkowania go jako wstecznika. Przypomnijmy jednak, że prymas poparł jednoznacz-

108 B. de Caché do W. A. v. Kaunitza, 28 III 1792, HHStA, Polen II 54, depesza 871, k. 118-119. Por. też Austria wobec Konstytucji 3 maja..., s. 191-192; Gazetka pisana, 21 III 1792, BN, Akc. 9830, k. 35.

109 SA do A. Debolego, 5 V 1792, AGAD, ZP nr 413, k. 377.

$110 \mathrm{~J}$. M ich hlski, Dyplomacja polska w latach 1764-1795, [w:] Historia dyplomacji polskiej, t. II (1572-1795), red. Z. Wójcik, Warszawa 1982, s. 483-705, a zwłaszcza 646-647, 670; Z. A n u s i k, Rzeczpospolita wobec wojny wschodniej (1787-1792) i wojny rosyjsko-szwedzkiej (1788-1790), [w:] Polska wobec wielkich konfliktów $w$ Europie nowożytnej. $Z$ dziejów dyplomacji $i$ stosunków międzynarodowych wXV-XVIII wieku, red. R. Skowron, Kraków 2009, s. 145-186, a zwłaszcza $172-173$.

111 Por. W. S moleński, op. cit., s. 361-366; F. S awi cka, Uroczystości dla uczczenia pierwszej rocznicy Konstytucji 3 Maja, [w:] „Rok Monarchii Konstytucyjnej”. Piśmiennictwo polskie lat 1791-1792 wobec Konstytucji 3 Maja, red. T. Kostkiewiczowa, Warszawa 1992, s. 177-194, a zwłaszcza 179-183.

112 Z. Z i elińs ka, op. cit., s. 465. 
nie Konstytucję 3 maja, i pomimo nacisków ze strony nuncjusza nie sprzeciwiał się projektowi autokefalii dla prawosławia. Nie był zwolennikiem monarszego absolutyzmu, lecz - podobnie jak jego królewski brat - umiarkowanej i parlamentarnej monarchii w stylu brytyjskim. Ponadto, przenosząc się z płaszczyzny interpretacji do ewaluacji, pytam się: czyż Poniatowski nie miał sporo racji w sprawie licytacji królewszczyzn? Czyż podziwiany przez niego Edmund Burke nie przewidział trafnie drogi Rewolucji Francuskiej do terroru i dechrystianizacji? I w końcu, czyż powinniśmy oczekiwać od osiemnastowiecznego arcybiskupa pobłażanie wobec nieograniczonego importu i drukowania dzieł szydzacych nie tylko $z$ duchowieństwa, ale nieraz także $z$ doktryny chrześcijańskiej? Postawa polityczna prymasa podczas Polskiej Rewolucji wciąż budzi kontrowersje. Nie sposób oczekiwać, aby takowe spory miały prędko ustać. Jego postawa w pozostałych mu dwóch latach życia również zasługuje na rewizję. 